\title{
A Rare Case of Open Dislocation of the Elbow with No Associated Neurovascular Injury Treated with Speed V-Y Muscleplasty
}

\author{
Ricardo Monreal ${ }^{1}$, Yblin Severiche ${ }^{2}$, Giovanni Osinaga ${ }^{3}$ and Eilen Monreal ${ }^{4}$ \\ ${ }^{1}$ Centro Médico MEDEX, República de Panamá 3065 2do piso, South America \\ ${ }^{2}$ Caja Petrolera de Salud. Santa Cruz, South America \\ ${ }^{3}$ Hospital Obrero No. 3, Caja Nacional de Salud, Santa Cruz, South America \\ ${ }^{4}$ School of Medicine, Ricardo Palma University, South America
}

Submission: June 27, 2017; Published: June 29, 2017

*Corresponding author: Ricardo Monreal, Centro Médico MEDEX, República de Panamá 3065 2do piso, San Isidro, and Clínicas Maison de Santé, Ave Chorrillos 171, Chorrillos, Lima, Peru, South America, Email: rmonreal59@yahoo.es

Abstract

An unusual case of open dislocation of the elbow in with no associated neurovascular injury is presented. Despite almost complete disruption of the ligaments and the muscular attachments manual reduction of the joint were impossible because the common flexors were so taught and speed V-Y muscleplasty was done in order to obtain a concentric joint.

Keywords: Elbow dislocation; Speed procedure; Neurovascular injury; Ligaments

\section{Introduction}

Closed posterior dislocation of the elbow is a common injury with good prognosis and its treatment includes reduction, immobilization and rehabilitation [1]. Open dislocations are infrequent, often associated with damage to the neuro vascular structures [2]. We present an unusual case of an open posteromedial dislocation of the elbow with no associated neurovascular injury treated with speed V-Y muscleplasty.

\section{Case Presentation}

A 41-year-old man fell from a height. He presented the left elbow was held fully extended and the lower end of the humerus was protruding through the wound in the antecubital fossa. The general condition was good and there was a palpable radial pulse and full sensation in the forearm and hand. Radiographs showed a postero-medial elbow dislocation (Figures $1 \mathrm{~A} \& 1 \mathrm{~B}$ ). The patient received tetanus prophylaxis and parenteral antibiotic therapy according the protocol. Intra-operative findings showed complete disruption of the collateral ligamentous complex and the common flexor origin on the medial aspect. The uninjured brachial artery and ulnar and median nerves were all visualized. After the wound was surgically cleaned with saline lavage, manual reduction of the joint was impossible and speed V-Y muscleplasty (posterior approach) was done in order to obtain a concentric joint (Figures 2A \& 2B). Following the procedure, examination of the patient no revealed any neurovascular impairment and the wound were primarily closed. Due the inherent instability and the elbow was placed in an above elbow back slab during for four weeks after which physiotherapy was started. Functional recovery was complete after four months.

Figure 1:
A. Photograph showing the open dislocation of the distal
humerus though the anterior cubital fossa.
B. APX-ray of elbow. Postero-medial dislocation of elbow.
Humerus displaced anteriorly.




\section{Orthopedics and Rheumatology Open Access Journal}

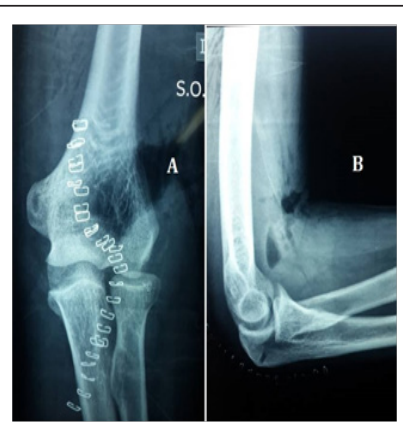

Figure 2: Post-operative $\mathrm{X}$-ray of the elbow.
A. AP and
B. Lateral views.

\section{Discussion}

Elbow dislocation associated with damage to the neuro vascular structures is well documented in several reports [2] but few cases with open dislocation with no associated neurovascular injury have been reported in the literature $[3,4]$. This case highlights the possibility of sustaining an open dislocation of the elbow with extensive soft tissue damage without neurovascular injury. Despite almost complete disruption of the ligaments and the muscular attachments, reduction was difficult because the common flexors were so taught. [3]. Speed V-Y muscleplasty is recommended to achieve a concentric joint reduction.

\section{Conflict of Interest}

No conflicts of interest were declared by the authors.

\section{References}

1. Josefsson PO, Gentz CF, Johnell O, Wendeberg B (1987) Surgical versus nonsurgical treatment of ligamentous injuries following dislocation of the elbow joint. A prospective randomized study. J Bone Joint Surg Am 69(4): 605-608.

2. Marnham R (1934) Dislocation of Elbow with Rupture of the Brachial Artery. British Journal of Surgery 22: 181.

3. Lui D, Boran S, Lenehan B, Jones D, Fogarty E, et al. (2007) Open postero-medial dislocation of the elbow in an 11-year old. A case report. Injury Extra 38: 365-368.

4. Roy BR, Alonso JA, Shaw DL (2002) Open antero-lateral dislocation of the elbow. A case report. BMC Musculoskeletal Disorders 3(1): 1.

\section{Your next submission with Juniper Publishers} will reach you the below assets

- Quality Editorial service

- Swift Peer Review

- Reprints availability

- E-prints Service

- Manuscript Podcast for convenient understanding

- Global attainment for your research

- Manuscript accessibility in different formats

( Pdf, E-pub, Full Text, Audio)

- Unceasing customer service

Track the below URL for one-step submission https://juniperpublishers.com/online-submission.php 